\title{
Colaboração, Solidariedade Social e Efetividade da Tutela Executiva Stricto Sensu
}

\author{
Luis Alberto Reicheit ${ }^{1}$
}

1 Introduçāo 2 Das Relaçōes Existentes entre o Princípio Democrático e a Garantia do Contraditóno. 3 Solidariedade Social Colaboraçầo entre os Sujeitos do Processo e Efetividade da Tutela Jurisdicional Executiva Stricto Sensu. 3.1 Colaboraçāo e Determinaçăo da Certeza, da Liquidez e da Exigibilidade da Obrigação Objeto do Pleito de Tutela Executiva Stricto Sensu. 3.2 A Colaboração e a Indicaçăo de Bens Passíveis de Penhora. 4 Conclusão Referências.

Resumo: Tomando como ponto de partida as relaçōes entre a princípio democrático e a garantia do contraditório, o presente ensaio examina as normas relativas à repartição de tarefas entre os sujeitos do processo e identifica a formaçấo de uma estrutura de colaboraçầo com vistas à efetividade da tutela jurisdicional executiva stricto sensu, a qual é a traduçāo da idéia de solidariedade social.

Palavras chave: Contraditónio. Processo Civil. Tutela Jurisdicional Executiva Stricto Sensu. Colaboração.

Abstract: taking as a stanting point the relations between the democratic principle and the hearsay rule, the present essay examines the rules conceming the tasks sharing among the process subjects, identifying the building of a collaboration structure related to the effectiventess of the stricto sensu executive jurisdictional protection, which is a translation of the idea of social solidarity.

Keywards: Hearsay. Civil Procedure. Stricto Sensu Executive Jurisdictional Protection. Collaboration.

\section{Introdução}

As transformações implementadas pelas Leis $\mathrm{n}^{\circ} 11.232$ 2005 e 11.382/2006 vêm produzindo um impacto que agora começa a ser sentido de maneira mais intensa pela comunidade jurídica. Tais alterações foram concebidas com um

\footnotetext{
"Mestre e Doutor pela Faculdade de Direito da UFRGS. Professor de Direito Processual Civil do UNIRITTER en Porto Alegre (RS). Procurador da Fazenda Nacional em Porto Alegre (RS).
} 
escopo primordial, qual seja o de assegurar maior efetividade à tutela jurisdicional executiva stricto sensu, diminuindo as distâncias existentes entre as tarefas de definição do direito aplicável a um caso proposto e de realização prática desse mesmo direito.

O rompimento com o paradigma anterior, passo necessário para a consecução dos objetivos que motivaram o surgimento das inovaçöes legislativas antes referidas, traz consigo o surgimento de um referencial novo, o qual pode e deve ser estudado a partir de diversas perspectivas possíveis. O presente ensaio propõe lançar luzes sobre um dos traços marcantes dessa nova realidade, qual seja a formaçăo de uma estrutura na qual os sujeitos do processo trabalham em conjunto com vistas à construção de uma tutela jurisdicional executiva stricto sensu dotada de verdadeira efetividade.

\section{Das Relações Existentes entre o Princípio Democrático e a Garantia do Contraditório}

Um ponto de partida importante a ser considerado com vistas à compreensão do funcionamento dessa dinâmica de trabalho conjunto em sede de processo de execução pode ser encontrada na convergência entre a função jurisdicional e o princípio democrático. A definição da idéía de jurisdição como uma atividade de exercício do poder do Estado na qual um terceiro imparcial, havendo sido autorizado para tanto pelo ordenamento jurídico, assume as tarefas de dizer o direito aplicável em face de um caso proposto para análise e de adotar as medidas práticas necessárias para assegurar o efetivo respeito às normas jurídicas aplicáveis traz, como decorrência, uma série de desdobramentos possíveis no que se refere à perspectiva de estudo ora referida.

Uma primeira dimensão a ser considerada é a que coloca $\mathrm{cm}$ evidếncia o exercício de poder do Estado como marca própria da atividade jurisdicional. Destaca se, sob esse ângulo, a necessidade de fazer com que a atuação do poder estatal 
sobre a esfera jurídica dos individuos que convivem em um determinado âmbito social guarde sintonia com a vontade daqueles que se submetem a tal império. Na medida em que a atividade jurisdicional compreende a construção de comandos nos quais vem individualizada a forma através da qual o Estado intervém na esfera jurídica dos sujeitos relacionados ao objeto do debate dos autos, impõe-se que seja assegurada aos envolvidos em tal panorama a possibilidade de manifestaçăo efetiva a respeito do conteúdo da decisão judicial. Se alguém tem sua esfera jurídica, de alguma forma exposta sob a sombra da espada de Dâmocles, isso somente deve ser aceito à luz do art. $1^{\circ}$ da Constituição Federal, na medida em que a atuaçấo estatal leve em conta as alegações daquele que sofrerá o peso dó exercício do poder do Estado. ${ }^{2}$

Das diversas projeçóes do princípio democrático inerentes ao funcionamento da estrutura estatal contemporânea, certamente a que mais parece ganhar peso é aquela na qual ele é instrumentalizado através da garantia do contraditório. Ainda que o direito de sufrágio e o caráter representativo nas votações legislativas sejam indispensáveis à estabilidade do Estado Democrático de Direito, é na seara da atuação da função jurisdicional que se dá a aproximação mais efetiva entre o exercício do poder estatal e a possibilidade de controle e de participaçăo por parte daqueles que a ele se subordinam na realidade pós-moderna. Em uma sociedade na qual vontades conflitantes coexistem em constante contraste e tensão, a possibilidade de particípaçăo na construção da decisão judicial é a ponte que viabiliza a menor distância entre a vontade dos sujeitos que têm seus interesses em debate nos autos e o exercício do poder do Estado que sobre eles se impōe.

\footnotetext{
${ }^{2}$ Nesse sentido, ver, por todos, DINAMARCO, Candido Rangel A Instrumentalidade do Processo. 7 ediçâo. Săo Paulo: Malheiros, 1999 , p. 9293, ao apontar que "no Estado de Direito, tem-se por indispensável fator legâtimante das decisóes in fieri a partícipação dos seus futuros destinatónios, a quem se assegura a observância do procedimento adequado e capaz de oferecer- Thes reais oporturidades de influir efetivamente e de modo equilibrado no teor do ato imperativo que virá.
} 
Nesse diapasão, observe-se que a garantia do contraditório assegura aos litigantes quatro direitos fundamentais: 0 direito a falar nos autos, o direito a terem suas manifestaçóes levadas em conta pelo juiz, o direito à formação de uma estrutura de trabalho conjunto entre eles e o órgão jurisdicional e, por fim, $o$ direito a não serem surpreendidos por decisōes em relação às quais năo thes tenha sido ofertada oportunidade de participação. O efetivo respeito ao seu conteúdo pode ser aferido, por sua vez, através de três projeçóes fundamentais: a observância das oportunidades juridicamente asseguradas às partes, para que possam se manifestar nos autos; a atribuição de um papel ativo no debate ao juiz, sem esvaziar o papel a ser desempenhado pelas partes; e a obediencia ao dever constitucional de motivação das decisões judiciais ${ }^{3}$

A garantia do contraditório acaba por se revelar não só uma projeção do princípio democrático, mas também do princípio fundamental da solidariedade social. Sob o manto. de tal perspectiva, cada indivíduo não é apenas o detentor de direitos e deveres em face dos seus pares, mas também exerce papéis no âmbito da sociedade como um todo e, nesse sentido, deve oferecer a sua parcela de contribuiçâo com vistas à realização de objetivos e à proteção de interesses que transcendem a esfera do meramente individual e adentram a dimensäo de um plano comum a todas as pessoas que convivem em um dado ambiente cultural. Trata-se, pois, de ver os sujeitos do processo como pessoas que se sujeitam a deveres e obrigaçôes que correspondem, de outro lado, a direitos e prestaçöes que se traduzem em beneficios de que desfrutam todos os integrantes de uma coletividade historicamente situada.

A existência do referido principio é amplamente reconhecida pela jurisprudência, revelando-se em projeçốes que permeiam os diversos ramos do saber jurídico, como o Direito

\footnotetext{
${ }^{3}$ Sobre a abordagem proposta, ver as consideraçöes que fiz em REICHELT, Luis Alberto. O Conteúdo da Garantia do Contraditório no Direito Processual Civil. In: Revista de Processo, 162 (2008): 330351.
} 
Tributário ${ }^{4}$ e o Direito Civil ${ }^{5}$. Sua matriz fundamental é radicada no disposto no art. $3^{\circ}$, I da Constituição Federal, no qual a construçâo de uma sóciedade solidária vem estabelecida como um objetivo a ser considerado na busca do significado de toda e qualquer norma inserida no ordenamento jurídico brasileiro. Trata-se, como se vê, de norma dotada de caráter imperativo, indicando claramente um objetivo a ser alcançado.

O respeito a tal noção, por sua vez, pode ser claramente vislumbrado se identificado também na forma como se dá a construção das regras processuais civis comprometidas com o escopo de determinar os limites em termos de ordem a serem respeitados na dinâmica de colaboração estabelecida entre os sujeitos do debate processual ${ }^{6} \mathrm{O}$ formalismo, nessa seara, constitui-se em poderosa ferramenta a serviço da ordenaçẫo do estado de coísas desejado pelo texto constitucional. ${ }^{7}$

\footnotetext{
4 No âmbito do Direito Tributáto, é possivel ver a aplicaçấo do principio da solidariedade social, exemplificativamente, nos seguintes julgados. Agravo Regimental no Agravo de Instrumento $\mathrm{n}^{\circ} 794.070 / \mathrm{PR}_{\text {, }}$ rel Min, Luiz Fux julgado pela Prímeira Turma do Superior Thibunal de Justica em 1411.2006, Recurso Especial n 625.589/RS, rel Min. Francisco Falcáo, julgado pela Primeira Turma do Superior Tribunal de Justiça em 21.02.2006, Recurso Ordinário em Mandado de Segurança $\mathrm{n}^{\circ} 20.242 / \mathrm{RJ}$, rel Min. Josê Delgado, julgado pela Primeira Turma do Superior Tribunal de Justica em 27.09.2005. Sobre o princípio da solidariedade no âmbito do Direito Civil ver Apelacão Cuvel no 70021871264 , Rel Des Araken de Assis, julgado pela Quarta Camara Clvel do Tribunal de Justiça do Estado do Rio Grande do Sul em 12.12.2007 Recurso Civeln 71001373208 , Rel Ricardo Torres Hermann, julgado pela Terceira Tuma Recursal Cvel do Rio Grande do Sul em 30102007 . Apelaçä Civel e Reexame Necessario n 70016532145 . Rel Des. Artur Arnildo Ludwig, julgado pela Sexta Camara Civel do Tribunal de Justiça do Estado do Rio Grande do Sul em 22.03.2007, Apelaçăo Cúel no 70015991433, Rel. Tasso Caubi Soares Delabary, julgado pela Nona Cámara Cuvel do Tribunal de Justiça do Estado do Rio Grande do Sul em 12122006.

* A respeito da importancia da ldeia de colaboraçao para a compreensão da dinâmica dialética do processo, ver ALVARO DE OLIVEIRA, Carlos Alberto. Poderes do Juize Visăo Cooperativa do Processo In AJURIS 90 (2003) 5584 , no qual o autor traz, ainda, ampla referencia bibliográfica a respeito do assinto.

${ }^{7}$ Sobre o tema, ver AIVARO DE OLIVEIRA, Carlos Albetto. Do Fomalismo no Processo Civil Săo Paulo Saraiva, 1997, especialmente p 6 , onde o autor enfatiza que of formalismo processual contem, no seu bojo, "a própria idéla de processo como organização da desordem, emprestando previsibilidade a todo o procadimento", apontando, ainda, que "se o processo näo obedecesse a uma ordem deteminada, cada ato devendo ser praticado
} 
A questăo anteriormente proposta ganha concretude na medida em que o processo se constitul em uma manifestação de atuaçäo integrada de pessoas que trabalham em conjunto, tendo suas atuaçōes reguladas em função da consecução de objetivos comuns consagrados pelo ordenamento jurídico. $A$ compreensão da forma como se dá a atuação das idéias de solidariedade social e de colaboração em tal contexto pressupóe, por sua vez, o exame dos limites impostos pelo ordenamento jurídico no que se refere ao agir dos sujeitos que interagem no debate processual.

O império da solidariedade social (e, por consequência, do dever de colaboraçáo processual) pode ser traduzido de inúmeras maneiras. $O$ grande desafio a ser considerado em todas elas é o da dentificação de mecantsmos que per mitam o controle da regularidade do desenvolvimento do debate dos autos em conformidade com tais ditames. Trata-se de apontar os limites a serem observados para que a transcendência dos limites da esfera do interesse puramente individual não se converta em instrumento a serviço da opressão da liberdade das partes pelo poder do Estado, nem, de outro lado, se converta em uma fórmula mágica que tudo promete e nada faz de concreto.

Sob essa perspectiva, uma das equações fundamentais a serem consideradas em um Estado Democrático de Direito é aquela que combina a liberdade das partes e o exercício de poder estatal sob o manto de duas condições fundamentais. Primeiramente, como já mencionado linhas atrás, impōe-se considerar que a existência de intervençâo na esfera individual de outrem mediante exercício de poder soberano somente se considera legítima na medida em que aqueles que sofrerão tal intervençāo possam participar de maneira efetiva na construção dessa manifestação de exercício de poder $\mathrm{A}$ essa primeira dimensão, soma-se, ainda, a necessidade de

a seu devido tempo e lugar, fách entender que o litiglo desembocaria numa disputa desordenada, sem limiles ou garantias para as partes, prevalecendo ou podendo prevalecer a arbitrariedade e a parcialidade do órgäo judicial ou a chicana do adversário". 
atendimento a outro requisito fundamental: a atividade de exercício do poder estatal e o exercício da liberdade de manifestação das partes somente são considerados legítimos na medida em que estejam em conformidade com uma pauta comum mínima de regras e princípios estabelecida em um determinado ordenamento jurídico. E é exatamente essa segunda perspectiva que faz com que se possa transcender de maneira a fazer com que o contraditório seja visto como uma garantia institucional do processo, indo além da idéia de simples proteção da parte contra o poder do Estado. Evoluise, nessa esteira, em direção à noçẫo de que a orientação dialética se impōe como traço inarredável que caracteriza o processo e a jurisdição, o qual não pode ser suprimido ou tratado como fruto de mera escolha política por parte do legislador. $^{3}$

Dessa dualidade de controles exsurgem conclusões eminentemente práticas. Sob o manto da primeíra condição antes apresentada, tem-se que é digna de reprovaçăo a conduta do juiz no sentido de decidir sem levar em conta a manifestação das partes ou, ao menos, abrir oportunidade para que estas possam se manifestar a respeito do thema decidendum. ${ }^{9}$ No que se refere ao segundo requisito, tem-se que o juiz está autorizado a indeferir a produção de provas que em nada colaborem para a elucidação do problema comum em torno do qual gira o debate processual. ${ }^{10} \mathrm{Em}$ ambos os casos, o que se observa é que a atuação da garantia do contraditório é estruturada em função de interesses que não são exclusivamente ligados às partes ou ao juiz. Os

\footnotetext{
${ }^{8}$ A expressão garantio institucional é utilizada, aqui, no significado dado por BONAVIDES, Paulo. Curso de Direito Constitucional. $13^{\text {z }}$ ediçăo. Săo Paulo: Malheiros Editores, 2003. p. 565 e seguintes e por CANOTILHO José Joaquim Gomes. Direito Constitucional e Teoria da Constituiçao. $6^{\mathrm{a}}$ edição, Coimbra: Almedina, 2002. p. 397-398.

" Assim também pensa ALVARO DE OLUVEIRA, Carlos Alberto. Poderes do Juiz $e$ Visco Cooperativa do Processo. cit, p. 62, apontando que "a sentença judicial só pode resultar do trabalho conjunto de todos os sujeitos do processo".

to Vide, sobre o ponto, BEDAQUE, José Roberto dos Santos. Poderes Instrutórios do Juiz. $2^{3}$ edição, Säo Paulo, Revista dos Tribunais, $200 \%$. Especialmente p. $154 \mathrm{e}$ seguintes.
} 
sujeitos do processo deixam de ser vistos apenas como titulares de direitos e passam a ser vistos como indivíduos que assumem papéis e recebem tarefas que se combinam em uma dinâmica orientada em função da necessidade de respeito a valores de ordem pública, cuja proteção é de interesse de toda a sociedade. É nesse ponto que o princípio do contraditório, tomado como garantia institucional do processo e da jurisdição, se entrelaça com a dimensão dos direitos fundamentais de terceira geração, na qual se situa a idéia de solidariedade social. ${ }^{11}$

Outra equação igualmente fundamental para a compreensão do dever de colaboração e da realização da idéia de solidariedade social no âmbito processual é a que envolve a associação de deveres e responsabilidades às partes. $\mathrm{O}$ estabelecimento de um compromisso conjunto dos sujeitos processuais com vistas ao efetivo exercício da jurisdição faz com que as partes devam observar limites no âmbito do agir individual, sendo sancionadas quandô do descumprimento desses deveres ou, ainda, quando do silêncio no exercício de determinadas faculdades. É o que ocorre, no primeíro caso, quando se observa a exístência de medidas destinadas à garantia da efetividade da tutela jurisdicional, na forma do art. 461 , $\S 4^{\circ}$ a $6^{\circ}$ do Código de Processo Civil, ou, ainda, no que tange à aplicação de regras sobre ônus de prova como aquelas inscritas no art. 333 do mesmo diploma processual. Em ambos os casos, os limites da liberdade individual do litigante são orientados ẹm função da necessidade de respeito à pauta mínima comum antes mencionada, estabelecendo-se um compromisso de todos com vistas à realização de objetivos que a todos interessam, em especial no que se refere à construção de um processo justo. ${ }^{12}$

\footnotetext{
* Sobre a caracterização dos direitos fundamentais de terceira geração, ver por todos, BONAVIDES, Paulo. cit. p. 569 e seguintes.

12 Sobre a déia do processo justo, ver, por todos, COMOGLIO, Luigi Paolo. Il "giusto processo" civile nella dimensione comparatistica. In: Revista de Processo, 108 (2002): 133-183.
} 
Como se vê, a idéia de colaboração, nesse contexto, significa algo que vai muito além da expressấo de um resultado decorrente do respeito a um dever exclusivamente ético. Colaboração, aqui, traduz a noção da existência de trabalho conjunto desenvolvido por pessoas sujeitas a um determinado regime jurídico no qual direitos, deveres e ônus convergem em uma direção comum, qual seja a da proteçẫo de determinados objetivos e valores fundamentais estabelecidos pelo mesmo ordenamento jurídico. É, pois, uma idéia em inegável sintonia com a noção de solidariedade social anteriormente mencionada que apresenta conteúdo eminentemente deontológico.

\section{Solidariedade Social, Colaboração entre os Sujeitos do Processo e Efetividade da Tutela Jurisdicional Executiva Stricto Sensu.}

A compreensão do conteúdo jurídico das idéias de colaboração e de solidariedade social constitui-se em uma tarefa ainda mais complexa quando se considera a sua forma de atuação no âmbito da tutela jurisdicional executiva stricto sensu. Reconhecida pela jurisprudência a aplicabilidade da garantia do contraditório tanto nos casos em que o processo é destinado a fornecer tutela em sede de conhecimento quanto naqueles em que a proteção é de natureza executiva, ${ }^{13}$ impóe-se, agora, identificar o conteúdo dessas manifestações no contexto antes apontado, delimitando quais permissóes, proibições ou obrigaçóes elas impôem aos sujeitos do debate dos autos.

\footnotetext{
13 Ver, nesse sentido, como exemplos de tal entendimento sedimentado em âmbito jurisprudencial: Agravo Regimental em Embargos de Divergencia em Recurso Especial $\mathrm{n}^{\circ}$ 41.855/SP, rel Min. José Delgado, julgado pela Primeira Seçáo do Superior Tribunal de Justiça em 12.08 1998, Recurso Especial n $685.251 / \mathrm{RS}$, rel. Min. Denise Arruda, julgado pela Primeira Turma do Superior Tribunal de Justiça em 02,08 2007; Recurso Especial $n^{\circ} 760.998 / G O$, sel. Min. Luiz Fux julgado pela Primeira Turma do Superior Tribunal de Justiça em 06,03,2007, Embargos de Divergência em Recurso Especial n $586.895 /$ RS, rel. Min. Laurita Vaz, julgado pela Corte Especial do Superior Tribunal de Justiça em 12.02.2007.
} 
3.1 Colaboração e determinação da certeza, da liquidez e da exígibilidade da obrigação objeto do pleito de tutela executiva stricto sensu

Uma primeira perspectiva na qual é possível observar a forma como se concretiza essa atividade de colaboração pode ser vista na imposição de deveres ao exeqüente relacionados à determinação da certeza, da liquidez e da exigibilidade da obrigação sobre a qual recai a atividade.

No que se refere à atividade de cumprimento da sentença, aponte-se que o prévio trabalho desenvolvido pelos sujeitos do processo com vistas à determinação do direito faz com que o título executivo seja considerado instrumento ${ }^{14}$ no qual vem veiculada uma forte presunção de existência de um direito subjetivo, Essa presunçấo, por certo, admite prova em sentido contrário, a qual somente tem razão de ser admitida nos casos em que presentes circunstâncias extremamente excepcionais, exigindo que o valor segurança jurídica - pilar fundamental da idéia de coisa julgada ${ }^{15}$ - seja relativizado em face do império de outro considerado mais importante pelo ordenamento jurídico.

Exemplos do fenômeno anteriormente descrito não faltam. E o que ocorre, verbi gratia, nos casos em que admissível a ação rescisória, medida pela qual o direito inscrito em uma decisão judicial transitada em julgado pode ter sua existência infirmada. Outra situação que se amolda à categorização antes apresentada nasce a partir da consideraçấo das possibili dades existentes em sede de embargos à execução baseada

\footnotetext{
${ }^{2} \mathrm{~A}$ construça or proposta pretende ir alén daquela apresentada por BUENO, Cassio Scarpinella. Curso Sistematizado de Direito Processual Cuil Vol 3 . Săo Paulo: Saraiva, 2008 p. 74,0 qual defende que o título executivo $e$ documento. Sobre ó conceito de instrumento, ver, por todos, MARINONI, Luiz Gulherme, ARENHART, Sergio Cruz Comentários ao Código de Processo Civil Vol 5 , tomo II. $2^{\text {a }}$ edição. São Paulo Revista dos Tribunais, 2005 , p. 237.

${ }^{15}$ Assinala CARNEIRO, Athos Gusmâ. Cumprimento da Sentença Cúl, Kio de Janeiro: Forense, 2007, p. 77, que "o respeito à garantía constitucional da coisa julgada é um razoável preço que o sistema juridico paga como contrapartida pela preservação de outros valores, somente podendo ser afastado em casos excepcionalissimos".
} 
em título executivo extrajudicial, substancialmente mais ricas do que aquelas presentes no caso de impugnação ao cumprimento de sentença judicial justamente em função da inexistência daquele prévio trabalho conjunto das partes com vistas à determinação quanto à existência do direito. ${ }^{16}$

As considerações anteriormente apresentadas podem ser aplicadas, ainda, no que se refere à exigibilidade da obrigação inscrita no título executivo. Pense-se, nesse sentido, no alcance ofertado à possibilidade de alegação de prescrição, tanto em sede de embargos à execução como em impugnaçấo ao cumprimento da sentença (ou, ainda, em sede de exceção de pré-executividade), ${ }^{17} \mathrm{ou}$, ainda, na possibilidade de o título executivo veicular entendimento diametralmente oposto àquele consolidado na jurisprudência do Supremo Tribunal Federal. Em tais casos, aquilo que se dava como certo quando as portas do debate executivo se abriram - a exigibilidade da obrigação - acaba sendo colocado em segundo plano em função da presença de fatores que não só traduzem a mesma idéia de segurança jurídica, mas também carregam consigo o compromisso com outros fins igualmente relevantes (efetividade do processo, proteção de direitos fundamentais etc). Trata-se de resultado de um juízo de proporcionalidade, em sentido estrito, envolvendo princípios de âmbito constitucional, o qual resta traduzido na equação construída

\footnotetext{
it Segue-se, aqui, na mesma esteira da constataça feita por BUENO, Cassio Scarpinella. cit., p. 475 , que aponta que o rol de materias inscrito no art $475-\mathrm{L}$ do Código de Processo Civil, referente à impugnaçăo ao cumprimento da sentença, é mais enxuto do que aquele inscrito no art 745 da mesma codificaçăo, concernente aos embargos à execução. Assim também, exemplificativamenté, WAMBIER, Luiz Rodrigues et alli. Curso Auançado de Processo Civil. Vol. 2. ga edição São Paulo: Revista dos Tribunais, 2007. p. 377. Posiçäo sensivelmente distinta a respeito do tema pode ser vista, de outro lado, em RODRIGUES, Marcelo Abelha. In: JORGE, Flavio Chem et alli. A Terceira Etapa da Reforma Processual Civil. São Paulo. Saraiva, 2006, p. 146.

${ }_{17}$ A respeito da relação entre prescrição e segurança jurídica, ver TON1OLO. Emesto José. A Prescrição Intercorrente na Execuçäo Fiscal. Río de Janeiro: Editora Lumen Juris, 2007, p. 72 73, em especial ao afirmar que "modificando-se o perfil valorativo do instituto, cada vez mais voltado à segurança jurídica da coletividade, nada impede que deixe de ser considerada como exceçöo ou defesa do devedor pora ser aplicada pelo magistrado ex officio, assim como ocorre com a decadência" (p. 73).
} 
a partir da combinação de regras de status eminentemente legal. ${ }^{18}$

A presença de tais presunçōes faz com que seja equivocado falar em um verdadeiro dever do exeqüente quanto à prova da certeza e da exigibilidade do direito. Assim ocorre na medida em que o ponto de partida da atividade executiva é o de que os interesses do exeqüente se encontram sob o manto da incidência de regras de experiência que sustentam a referida presunção. Em havendo produção de provas capazes de infirmar a conclusão preliminarmente veiculada no título executivo quanto à existência ou à̀ exigibilidade da obrigação nele inscrita, recai sobre os ombros do credor um ônus de provar o contrário. Restando o julgador em estado de dúvida ao final do processo no que se refere à prova de tais atributos da obrigação objeto do pleito de tutela jurisdicional executiva, o prejuízo recairá sobre os ombros daquele que demanda a tutela jurisdicional. ${ }^{19}$

No que tange à liquidez da obrigação inscrita no título executivo, o quadro a ser desenhado é consideravelmente mais complexo. A presença de debate nos autos com vistas à liquidação da obrigaçăo inscrita no título executivo constitui-se em manifestação inegável da idéia de colaboração no processo civil. Impõe-se à parte exeqüente, inicialmente, o ônus de apresentar sua posição quanto ao alcance da prestação a ser satisfeita mediante o emprego de medidas executivas, mas também cumpre à contraparte o ônus de infirmar tais

\footnotetext{
19. Sobre o funcionamento do raciocínio em sede de proporcionalidade em sentido estrito, passo úlimo no emprego do postulado normalivo aplicativo da proporcionalidade, ver, por todos, ÁvilA Humberto. Teoria dos Princupios - da definição à apliçação dos princípios jurídicos. Sâo Paulo: Malheitos Editores, 2003, passim.

${ }^{19}$ A respelto do funcionamento das regras sobre ônus de prova como regras de julgamento, ver, em uma visáo clássica, MICHEII, Gian Antonio La Carga de la Prueba. Traduzido para o espanhol por MELENDO, Santiago Sentís. Buenos Airest Fdiciones Juridicas Europa-America, 1961 , p. 193, e, numa abordagem contemporânea da realidade do processo civil brasileiro, ALVES, Maristela da Silva. Esboço Sobre o Significado do Orus de Prova no Processo Ciuil. In: KNIJNIK, Danilo (org). Prova Judiciária - Estudos Sobre o Novo Direito Probatório, Porto Alegre: Ljvrana do Advogado, 2007, p. $203-218$
} 
argumentos. Nesse contexto, não só as manifestações das partes a respeito dos termos da liquidação são valoradas pelo ordenamento jurídico, mas também o silêncio dos litigantes acaba por ensejar a produção de resultados jurídicos diversos.

Um exemplo emblemático da sistemática anteriormente descrita pode ser visto na interpretação emprestada ao art. $475-\mathrm{B}, \S \S 1^{\circ}$ e $2^{\circ}$ do Código de Processo Civil. Nos casos em que a elaboração da memória do cálculo depender de dados existentes em poder do devedor, o juiz, a requerimento do credor, poderá requisitá-los, fixando prazo de até trinta dias para o cumprimento da diligência. Năo atendida a determinação judicial no prazo apontado nem apresentada justificativa plausível, o silêncio do executado poderá ser tomado pelo julgador em um juízo de valoração crítica, como concordância do devedor com o cálculo exeqüendo. Alerte-se, nesse ponto, que o exccutado será sancionado, em tal hipótese, com a perda da oportunidade de apresentação de impugnação ao cumprimento da sentença fundamentada exclusivamente em iliquidez da obrigação exeqüenda decorrente da desconsideração de tais dados na feitura do cálculo. Trata-se, aqui, de mais um sintomático exemplo da existência de norma que impóe o dever de colaboraçấo entre exeqüente e executado com vistas ao aprimoramento da qualidade da tutela jurisdicional.

Outra manifestação eloqüente do raciocínio ora exposto pode ser vista no art. $475-\mathrm{B}, \S 4^{\circ}$ do Código de Processo Civil. Segundo tal comando, caso o credor venha a concordar com o cálculo apresentado pela contadoria judicial, far-se-á a execução pelo valor apurado pelo expert. Se, contudo, houver contraposição de parte do exeqüente a tal cálculo, a execução segue pela quantia pretendida pela parte, mas a penhora é restrita ao montante apurado pela contadoria. $O$ silêncio do exeqüente em face do cálculo apresentado pelo

20 Assim THEODORO JR. Humberto. As Novas Reformas do Código de Frocesso Civil. Rio de Janeiro: Forense, 2006. p. 192. 
órgão auxiliar do julgador somente pode ser valorado como manifestação de concordância ou nấo na medida em que houver alerta expresso em tal decisão judicial a respeito das conseqüências a serem aplicadas em tal hipótese.

Uma linha semelhante permeia, ainda, a justificativa que permetra no art $475-\mathrm{B}, \S 3^{\circ}$ da lei processual civil ao estipular a atribuição de poderes ao juiz com vistas à determinação da liquidez da obrigação inscrita no título executivo judicial. $O$ fato de haver uma repartição de ônus entre as partes no que tange a tal matéria não significa, por certo, que o julgador deva atuar como mero espectador do exercício da liberdade dos litigantes. Ao contrário, exerce o juiz um papel ativo no debate quando, observando que a memónia apresentada pelo exeqüente aparentemente excede os limites da decisão exeqüenda, decide por remeter os autos à contadoria para aferir a correção ou não do quantum a ser demandado. Esse mesmo espírito que justifica os limites da outorga de um papel ativo ao órgão junisdicional permite, ainda, que o julgador, como medida alternativa àquela indicada no comando ora citado, intime a parte exeqüente para que esclareça ou corrija o cálculo naquilo em que for obscuro ou errado. ${ }^{21}$ Também é sob o signo dessa orientação que se mostra legítimo que o julgador adote uma postura crítica em relação ao cálculo apresentado, rejeitando o laudo da contadoria, ou, ainda, determinando a realização de outro cálculo com vistas à correta liquidação da sentença. Tudo isso ocorre justamente porque tanto o regime jurídico aplicável à conduta das partes quanto aquele referente ao agir do julgador têm como norte um objetivo comum, qual seja a efetividade da tutela jurisdicional executiva stricto sensu.

Todo esse quadro é permeado, ainda, pelos deveres impostos ao julgador com vistas à direçẩo formal e material do processo. Ao juiz cumpre a tarefa de zelar pela regular

\footnotetext{
21 A observação é feita por FLACH, Daisson. In: AlvARO DE OLIVElRA, Carlos Alberto (coord). A Nova Execução - Comentários à Lei $r{ }^{\circ} 11.232$, de 22 de dezembro de 2005. Ruio de Janeiro: Forense, 2006. p. 57-58.
} 
tramitaçăo da marcha processual, fazendo com que sejam respeitados os prazos e formas estabelecidas pelo ordenamento jurídico com vistas à definiçấo da dimensão dentro da qual será considerada legítima a sua atuação no que se refere à prática de atos executivos. Da mesma forma, cabe ao julgador conduzir a atividade de liquidação da sentença de maneira que o resultado ao final dela alcançado seja o melhor possível não só no que se refere à celeridade da marcha processual, mas também no que tange ao conteúdo da prestação jurisdicional $^{22}$ A colaboraçẫo trazida pelas partes não exclui, por certo, a irrecusável tarefa outorgada pelo ordenamento ao juiz. $^{23}$

Destaque especial, nesse sentido, deve ser dado às possibilidades abertas ao julgador de conhecer ex officio de defeitos que permeíem os cálculos apresentados pelas partes, em especial naquilo em que o preenchimento de lacunas em sede de liquidação de sentença depender de interpretação do alcance do ordenamento jurídico. É o que ocorre, por exemplo, no caso de o juiz impor às partes o dever de observar a fórmula estabelecida em lei com vistas ao cálculo do imposto. sobre a renda naqueles casos em que se busque apurar o valor do indébito apurado a título de tal prestação tributária. Nessa esteira, não basta ao exeqüente simplesmente somar os valores que foram objeto de retenção indevida ao longo do exercício financeiro, mas é preciso que seja apresentado cálculo que espelhe a fórmula empregada em uma declaraçăo anual de imposto sobre a renda, levando em conta todos os fatores que integram tal equação (deduçốes permitidas por lei outros rendimentos auferidos ao longo do ano

\footnotetext{
${ }^{22}$ Sobre o problema da direcão do processo em sentido material (when it tends to clarify the cause-material, eg., examination of a wimess by the cout") e em sentido formal (when it has to do with the external progress of the cause, e.g. setting a cause for heaning"), ver MILLAR, Robert Wyness. The Formative Principles of Civil Procedure. In: ENGELMANN Arthur (org.). A History of Continental Ciull Procedure. Nova Iorque: Augustus M. Kelley Publishers, 1969, p. 23.

2: A reflexăo ora proposta pode ser vista, sob a forma de uma afirmação em sede de teoria geral, na liçăo de DALLAGNOL, Antonio. Comentánios do Código de Frocesso

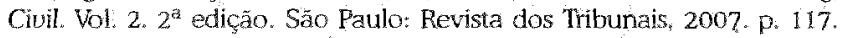


que sejam considerados tributáveis etc.), e não apenas aqueles que interessam a uma determinada parte. Se, de um lado, cabe às partes o dever de produzir a prova quanto à ocorrência ou não da retenção da tributação pela fonte pagadora, isso não significa que o juiz não deva ter atenção redobrada no que se refere à equação na qual tais valores atuam como fatores. ${ }^{24}$

\subsection{A colaboração e a indicação de bens passíveis de penhora}

Uma referência importante a ser considerada no novo paradigma hoje vigente em sede de processo de execução diz respeito ao alcance do dever de colaboração entre os sujeitos do processo com vistas à identificação dos bens sobre os quais pode recair a penhora.

Para que se possa efetuar uma análise atenta quanto ao alcance de tal dever de colaboração, impõe-se trazer, inicialmente, o marco regulatório estabelecido pelo Código de Processo Civil. Nesse sentido, cumpre mencionar, em primeiro lugar, o constante do art. $652, \S 3^{\circ}$, que prevê a possibilidade de estabelecimento ope iudicis de um dever imponivel ao executado de informar nos autos a existência de tais bens. De outro lado, 0 art. $600, \mathrm{~V}$ do mesmo diploma legal qualifica como ato atentatório à dignidade da Justiça a conduta da parte que, regularmente intimada, não indica ao juiz, no prazo de cinco dias, quais são e onde se encontram os bens ou valores de sua propriedade que podem estar sujeitos à penhora nem apresenta qualquer justificativa. ${ }^{25}$ Também merece atenção, ainda, o disposto no art. $652 \$ 2^{\circ}$, pelo qual é facultado

\footnotetext{
2A Sobre o tema, ver, exemplificativamente, as seguintes julgados: Apelação Civel $n^{\circ}$ 200572000135335. Rel. Juíza Marciane Bonzanini, julgada pela Segunda Turma do Tribunal Regional Federal da $4^{a}$ Região em 03/06/2008; Apelação Civel no 200572010035295. Rel Des. Luciane Amaral Correa Müch, julgada pela Segunda Turma do Tribunal Regional Federal da $4^{\text {a }}$ Região em 06/05/2008; Apelação Crvel $n^{\circ}$ 200671000273953, Rel Juiz Eloy Bernst Justo, julgada pela Segunda Turma do Tribunal Regional Federal da $4^{2}$ Regiâo em 22/01/2008, Apelaçá Cível no 200672000144869, Rel Jujz Leandro Paulsen, julgada pela Segunda Tuma do Tribunal Regional Federal da 4 . Regiăo em 02/10/2007.

25 Nesse sentido, THEODORO JR., Humberto. A Reforma da Execução do Tr̆tulo Extrajudicial Rio de Janeiro: Forense, 2007. p. 61 e MITIDIERO, Danid. In; ALVARO DE OLVEIRA, Caros Albeto (coord). A Nova Execução de Tthulos Extrajudicais. Rio de Janeiro: Forense, 2007. p. 57.
} 
ao exeqüente indicar quais os bens sobre os quais entende que deva recair a penhora.

Do olhar atento para tais comandos é possivel identificar um determinado estado de coisas que vincula os sujeitos do debate processual. Surge, nesse contexto normativo, um panorama no qual todos os participantes da dialética dos autos exercem papéis e exercem atividades que se entrelaçam em torno de um escopo comum. Sob o signo de tal orientação, os direitos, deveres, ônus e faculdades repartidos entre os sujeitos do debate processual sāo teleologicamente ordenados em função da viabilização da constrição de bens do executado, passo integrante da dinâmica de atos processuais que tende a culminar com a satisfação daquele interesse juridicamente protegido de que o exequente alega ser titular. A presença desse ponto de convergência entre tais posiçōes serve como indicativo de que a divisão de cargas entre autor, juiz e réu é absolutamente equilibrada, constituindo-se em um meio que tende a assegurar a efetiva produção dos resultados que dele se espera.

De se notar que, sob o prisma da questão ora examinada, a efetividade do processo passa, necessariamente, pela presença de um juiz que não se limite a observar a atuação das partes, mas que com elas atue na construção do debate em sede de atividade processual executiva. $O$ silêncio do juiz, em certas circunstâncias, leva nấo só ao esvaziamento do espírito de colaboração com o qual se compromete o Código de Processo Civil, mas também ao insucesso do próprio debate processual, que corre o risco de se transformar em um ritual estéril.

Ponto interessante a ser considerado reside na possibilidade de emprego de penhora online pelo julgador, questão que vem sendo vista pela jurisprudência cível como medida que se justifica nos casos em que demonstrado o esgotamento das diligências na busca de bens em nome do executado ${ }^{26}$

\footnotetext{
2h A respefto do entendimento ora citado, veja-se os seguintes julgados: Agravo de Instrumento $n^{\circ} 200804000141615$, Rel. Juiz Marcelo de Nardi julgado pela Primeira
} 
Por certo que a prova a ser exigida em tal contexto será indiciária, não se impondo ao exeqüente o desafío invencível de produzir prova inequívoca quanto à inexistência de qualquer componente a compor o patrimônio do executado. A aferiçăo da força a ser associada a prova indiciária dependerá, fundamentalmente, do contexto no qual desenvolve a atividade de instrução. Sob esse prisma, é razoável que se exija a demonstração da ausência de bens imóveis no município em que reside o demandado, mas, de outro lado, é absolutamente exagerada a conduta do julgador que, sob o argumento da referida necessidade de esgotamento dos meios de prova, acaba por inviabilizar a satisfação do crédito do demandante.

A presença de um juiz ativo também é determinante para que se possa garantir a efetiva aplicação do disposto no art. 655-A do Código de Processo Civil. Nesse sentido, o ativismo não deve ficar adstrito apenas à prolação da decísăo que autoriza o emprego do sistema BACEN-JUD, mas também no que tange à adoção de medidas em sede de instrução que permitam complementar aquele quadro incompleto desenhado a partir dos esforços empreendidos pela parte exequente nos limites de suas forças. Lembre-se, como já referido anteriormente, que a não apresentação, pelo executado, de notícia quanto aos valores que podem ser penhorados constitui-se em ato atentatório à dignidade da Justiça, ensejando, inclusive, a aplicaçăo de multa que pode montar a até vinte por cento do valor executado, na forma do determinado no art 601 do mesmo diploma legal.

Observe-se, ainda, que o dever de indicação de bens imposto pelos arts. $652 \$ 3^{\circ}$ e $600, \mathrm{~V}$ do Código de Processo Civil vem acompanhado, ainda, de uma regra de ônus de prova que é construída a partir da exegese do constante do art.

\footnotetext{
Turma do Tibunal Regional Federal da $4^{\text {a }}$ Regiâo, em 27/08/2008; Agravo de Instrumento $n^{\circ} 200704000315091$, Rel. Des. Maria Lucia Luz Leiria, julgado pela

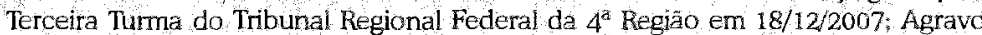
de Instrumento $n^{\circ} 200704000315091$, Rel. Juiz Eloy Bernst Justo, julgado pela Segunde Turma do Tribunal Regional Federal da $4^{a}$ Região, em 06/11/2007.
} 
649, IV. Por força desse aspecto, a impenhorabilidade da conta salário $^{27}$ fica condicionada à demonstraçăo de tal situaçăo, ainda que por indícios, pela parte interessada: havendo dúvida quanto a tal aspecto, a regra de julgamento a ser utilizada determina que o juiz deve decidir no sentido de que a constrição é lícita.

\section{Conclusão}

Sob o império da solidariedade social, a atuação dos sujeitos que dialogam no debate dos autos deve ser vista como verdadeiro trabalho conjunto, no qual as tarefas associadas a cada um deles é regida em função do todo maior no qual se inserem. A cooperação entre os participantes da dialética processual năo se constitui em um simples protocolo de intenções situado no plano meramente ético, mas extrapola essas fronteiras e adentra o plano deôntico. A existência de real colaboração entre autor, juiz e réu pressupōe o correto entrelaçamento entre os direitos, os deveres, os ônus e as faculdades que lhes são associadas, que deixam de constituir problemas situados na esfera exclusivamente individual de cada um dos sujeitos do processo e passam a ser vistos como engrenagens de uma mecânica teleologicamente ordenada.

O desafio a ser enfrentado nos dias de hoje é o de ir além da simples promessa segundo a qual o processo deve perseguir os fins consagrados pelo ordenamento jurídico. Chegou o tempo no qual a promessa deve ser acompanhada pela presença de indicativos concretos que permitam alimentar a esperança daqueles que vêem no processo um caminho tendente à realizaçâo de justiça. A consagração de normas que impôem a efetiva colaboração entre os sujeitos do processo não só é uma exigência imposta pelo ordenamento jurídico

\footnotetext{
${ }^{27}$ Sobre o ponto, ver, exemplificativamente, as seguintes decisốs: Agravo de Instrumento $n^{\circ} 70021110697$. Rel. Des. Jorge Luiz Lopes do Canto, julgado pela Decima Segunda Camara Civel do Tribunal de Justiça do Estado do Río Grande do Sul em 22. 1 1.2007; Agravo de Instrumento n ${ }^{\circ}$ 70007422967, Rel. Des. Claudir Fidelis Faccenda, julgado pela Déma Sexta Câmara Cvel do Tribunal.
} 
constitucional, mas também é um sinal de que o compromisso com a efetividade da tutela jurisdicional vincula a todos os participantes do processo.

\section{Referências}

ALVARO DE OLIVEIRA, Carlos Alberto (coord.). A Nova Execuçāo-Comentários à Lei $n^{\circ} 11.232$, de 22 de dezembro de 2005. Rio de Janeiro: Forense, 2006.

ALVARO DE OLIVEIRA, Carlos Alberto (coord). A Nova Execuçāo de Títulos Exirajudiciais. Rio de Janeiro Forense, 2007.

ALVARO DE OLIVEIRA, Carlos Alberto. Do Formalismo no Processo Ciuil. São Paulo: Saraiva, 1997. $55-84$.

Poderes do Juiz e Visäo Cooperativa do Processo. In: AJURIS, 90 (2003):

ALVES, Maristela da Silva. Esboço Sobre o Significado do Onus de Prova no Processo Civil In: KNIJNIK, Darilo (org.). Prova Judiciária - Estudos Sobre o Novo Direito Probatórío. Porto Alegre: Livraria do Advogado, 2007.

ÁVILA, Humberto. Teoria dos Princípios-da definição à aplicaçāo dos princí pios jurídicos. Sầ Paulo: Malheiros Editores 2003

BEDAQUE, José Roberto dos Santos. Poderes Instrutónios do Juiz. $2^{a}$ edição, São Paulo, Revista dos Tribunais, 2001 .

BONAVIDES, Paulo Curso de Direito Constitucional. 1 $3^{a}$ edição. São Paulo: Malheiros Editores, 2003.

BUENO, Cassio Scarpinella Curso Sistematizado de Direito Processual Civil. Vol 3. Säo Paulo Saraiva, 2008.

CANOTILHO, José Joaquim Gomes Direito Constitucional e Teoria da Constiauçâo . $6^{a}$ ediçäo. Coimbra: Almedina, 2002.

CARNEIRO, Athos Gusmäo. Cumprimento da Sentença Civil. Rio de Janeiro: Forense; 2007.

COMOGLIO, Luigi Paolo. Il 'giusto processo civile nella dimensione comparatistica. In: Revista de Processo, 108 (2002): 133-183.

DALLAGNOL Antonio. Comentários do Código de Processo Civil. Vol 2. $2^{\text {a }}$ edição. São Paulo: Revista dos Tribunais, 2007.

DINAMARCO, Cândido Rangel A Instrumentalidade do Processo. $7^{\text {a }}$ edição. São Paulo: Malheiros, 1999 . 
JORGE, Flávio Cheim et alli. A Terceira Etapa da Reforma Processual Civil. São Paulo Saraiva, 2006.

MARINONI, Luiz Guilheme; ARENHART, Sérglo Cruz Comentários ao Código

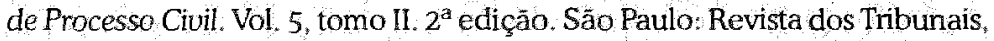
2005.

MICHELI, Gian Antonio. La Carga de la Prueba. Traduzido para o espanhol por MELENDO, Santiago Sentís. Buenos Aires: Ediciones Junidicas Europa-America, 1961.

MILLAR, Robert Wyness. The Formative Principles of Civil Procedure In: ENGELMANN, Arthur (org). A History of Continental Civil Procedure Nova Iorque, Augustus M. Kelley Publishers, 1969.

THEODORO JR, Humberto. As Novas Reformas do Codigo de Frocesso Civil. Rio de Janeiro: Forense, 2006. se, 2007.

A Reforma da Execução do Titulo Extrajudicial. Rio de Janeiro: Foren-

TON1OLO, Emesto José. A Prescriçăo Intercorrente na Execuçăo Fiscal Río de Janeiro Editora Lumen Juris, 2007.

REICHELT, Luis Alberto. O Conteudo da Garantia do Contraditónio no Direito Processual Civil. In: Revista de Processo, 162 (2008): 330-351.

WAMBIER, Luiz Rodrigues et alli. Curso Avançado de Processo Civil. Vol 2. São Paulo: Revista dos Tribunais, 2007. 